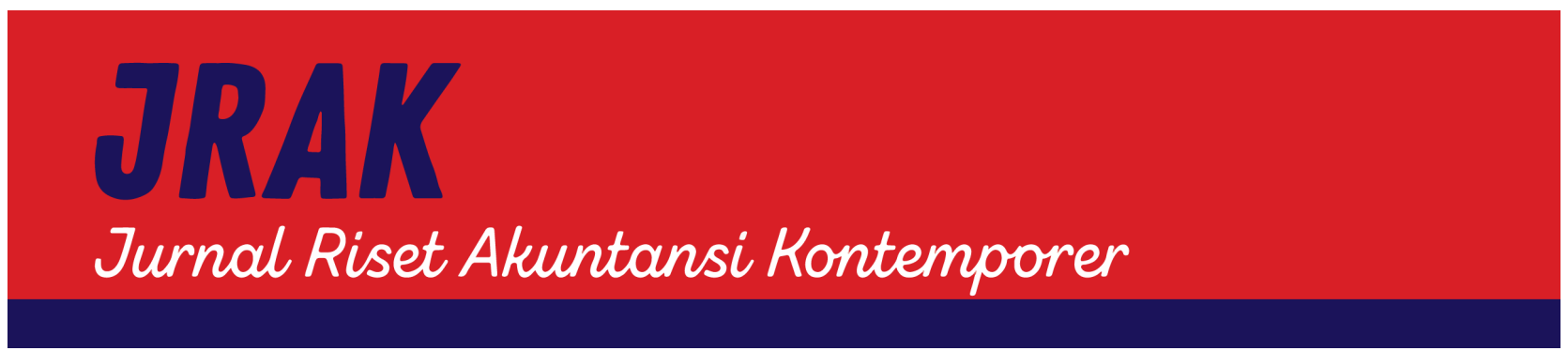

\title{
AUDIT TENURE, AUDITOR EXPERIENCE, INDEPENDENCY, AND TASK COMPLEXITY ON AUDIT JUDGEMENT
}

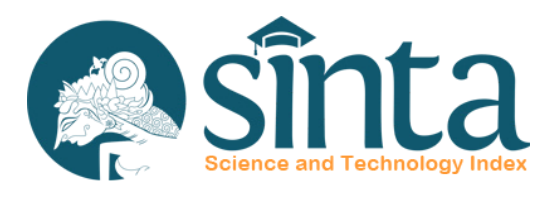

https://journal.unpas.ac.id/index.php/jrak/index

Arie Pratania Putri ${ }^{1} \bowtie$, Nur Nabila ${ }^{2}$, Viony Augustin $^{3}$, Fellia $^{4}$

1,2,3,4 Universitas Prima Indonesia

$\triangle$ arieprataniaputri@unprimdn.ac.id

J1. Sikambing No.simpang, Sei Putih Tim. I, Kec. Medan Petisah, Kota Medan

\section{Article Info}

History of Article

Received: $24 / 12 / 2020$

Revised: 10/3/2021

Published: $25 / 4 / 2021$

Jurnal Riset Akuntansi Kontemporer

Volume 13, No. 1, April 2021, Page 7-12

ISSN 2088-5091 (Print)

ISSN 2597-6826 (Online)

Keywords: audit tenure; auditor experience; independency; task complexity; audit judgement

\begin{abstract}
Research was conducted in KAP in the area of Medan with the primary data collection method using questionnaire. The sampling was conducted by purposive sampling technique and the sample used in this research was 82 respondent. The method of analysis was used is multiple linear regression analysis using SPSS. The result of research showed that audit tenure auditor experience and independency have significant positive effect on audit judgement, task complexity has not significant effect.
\end{abstract}

\section{INTRODUCTION}

Auditors from the Public Accounting Firm are tasked with assisting companies in producing and evaluating financial reports and publishing the audit reports (Sitohang, 2016). Over time, more and more public accounting firms have improved their quality in facing competition in order to increase the number of clients they have. In carrying out their duties and obligations, auditors will carry out their duties as well as possible so that clients are satisfied and will return to using their services when they need them (Sofiani and Tjondro, 2014).

The clients (companies) who come to the auditors hope that other people who read and understand the business can think that the client company is the best through published financial reports. Auditors are required to provide effective and satisfying audit results for their service users (Pinto, et. al. 2020). This makes auditors have to work hard to ensure every truth of the reports and judgments made because they will always affect the client company. Therefore, auditors need to be very careful, and use professional judgment to plan carefully, carry out all procedures and make conclusions based on clear and objective examinations so that they can report good audit results. (Sila, 2015; Hasan \& Andreas, 2019).

In carrying out their duties, auditors are also not free from mistakes in conducting audits (Upawita and Pertiwi, 2017) as in the case of the public accounting firm Tanubrata, Sutanto, Fahmi, Bambang and Partners with Public Accountant (PA) Kasner Sirumapea on the 2018 Financial Report. This began when two Garuda 
Indonesia commissioners, Chairal Tanjung and Dony Oskaria, refused to sign an approval for the results of the 2018 financial statements. Regarding the recording of transactions with Mahata, both of them had different views on the income account of US \$ 239.94 million. Even though there has been no receipt of incoming funds from the Mahata until the end of 2018.

In the case of PT Garuda Indonesia, Tbk in 2018, the Ministry of Finance described 3 (three) negligence of the Public Accountant (PA) in auditing the financial statements. First, the concerned public accountants have not accurately assessed the substance of the transactions in the accounting treatment for the recognition of receivables and other income. This is because this public accountant has acknowledged in advance the receivables that the company has not received in nominal terms. Second, for the accounting treatment that is in accordance with the substance of the transaction agreement, the public accountant has not yet obtained sufficient audit evidence. Finally, public accountants also cannot interpret the facts that exist after the date of their financial statements.

From the above phenomenon, it shows that the auditor's judgment is needed in the financial statements, even when the judgment has been given, it does not rule out the possibility of errors that will occur (Murthada, 2018). According to Widyanti (2015) audit judgment is needed as an auditor's consideration to respond the information relating to providing an opinion or decision on a financial report. According to Rozalina and Rachmat (2020), the auditor's consideration is the auditor's attitude in responding to existing information that will affect the final documentation of evidence or opinion in making the auditor's decision on an entity's financial statements or in the form of an audit report. If there is an error in the auditing of the financial statements by the auditor, it will have an impact on the business relationship, the auditor's reputation and the credibility of the auditor and the relevant public accounting firm.

Audit Tenure is a the audit period or audit engagement period between the entity (client) and the auditor regarding the use of audit services within the public accounting firm agreed for a certain period (Asmara \& Situanti, 2018; Sari, et. al. 2019). The length of time that the audit engagement is considered can affect the auditor in producing judgments. This is because the longer an auditor cooperates with clients, it makes it easier for auditors to design a more effective audit and produce quality audit judgments (Rustiarini and Sugiarti, 2011). Even so, the government has set a time limitation between public accounting firm and consecutive clients, namely a maximum of 6 (six) years and by a public accountant for a maximum of 3 (three) years as regulated in Regulation of the Minister of Finance Number 17/PMK.01/2008 (Putri, 2014).

The learning process and the development of a person's potential for behavior are experiences (Asih 2006 in Praditaningrum, 2012). With a lot of audit experience by an auditor, it will be very helpful in completing his duties which have a tendency towards the same pattern (Putra, 2016). The auditor's experience leads to his experience in examining financial statements, as well as the total duration of the engagement and the assessment of an issue. An auditor who has a lot of experience, the better for him to carry out complex tasks. (Saputra and Muhammad, 2019). By having good experience, it is believed that the resulting audit judgment will also be of good quality.

This relates to the independence of an auditor. It is feared that the length of the audit engagement will result in a lack of credibility in producing financial statements (Al-Thuneibat, et. al. 2011, in Bessie 2010; Harahap \& Syalfia, 2020). Independence means the attitude of an auditor who is free from any influence, impartial and uncontrollable and dependent on other parties (Eny and Mappanyukki, 2020). Each auditor must maintain integrity and objectivity in the conduct of his audit (Susanto, 2020). Therefore, the auditor should be independent both from the client, the users of the financial statements and the auditor's own interests (Putri, 2014). This independence triggers a statement that how long an auditor is given audit time, and how much experience the auditor has gained, if the auditor's independence is not easily shaken, the resulting audit judgment will also be better and in accordance with existing facts. In addition, audit decision makers, for example investors, also rely more on audit information provided by sources deemed to have a high level of competence and independence. Therefore, auditors are required to have an independent attitude from their clients in submitting audit reports (judgment) so that the level of investor confidence in the disclosure of audit reports will emerge (Williams, 2016).

In addition to the three things above, Sari and Ruhiyat (2017); Komalasari \& Hernawati (2015) suggest that task complexity also affects audit judgment, where high complexity can damage the judgment made by the auditor. Task complexity is a process of integrating problems that are owned by a decision maker that raises individual perceptions of the difficulty of the task at hand due to limited capacity, memory and abilities (Praditaningrum, 2012; Ayuni and Suprasto 2016 in Priyoga and Ayem, 2019). In auditing activities, the high complexity of the audit can lead to a decrease in the performance of the auditors which results in a decrease in the quality of the audit (Adnyani, et. al. 2020). So that complex tasks can be completed smoothly, decision 
makers or auditors are required to always develop a mindset, innovation and creativity (Sari and Ruhiyat, 2017). An auditor who is able to face and complete complex tasks and understand the entity being audited, the judgment produced by the auditor will be more precise and accurate (Noor, et. al. 2019; Widyakusuma, et. al. 2019).

\section{METHOD}

Type of research that researchers use is descriptive and tends to use analysis. The approach used is quantitative research with the nature of explanatory descriptive research which explains the position of the variables studied and their relationship to one another.

The population in this study were all public accounting firms in Medan City registered with the Indonesian Institute of Public Accountants (IAPI) 2020, namely 23 public accounting firms, with a sample of 82 respondents from 7 public accounting firms in Medan City. For sampling, the sampling technique used was purposive sampling. The criteria for sampling are: (1) the public accounting firm is located in Medan City; (2) the public accountant firm is willing to be used as a place of research; (3) the auditor has at least one year of work experience.

The type of data used is primary data obtained by using a questionnaire that has been arranged in such a way as to obtain information about the auditor's views on the variables taken by the multiple linear regression analysis method processed using SPSS software.

\section{RESULT}

Based on the Directory 2020 book, there are 23 public accounting firms located in Medan, but 7 public accounting firms are willing to fill out the questionnaire, and of the 100 questionnaires that have been distributed, only 82 questionnaires have returned or with a percentage of $82 \%$. The public accounting firms who were the respondents in the study are in Table 1.

Table 1. Research Sample

\begin{tabular}{cl}
\hline No. & Name of Public Accounting Firms \\
\hline 1. & KAP Drs. Albert Silalahi \& Rekan (Cabang) \\
2. & KAP Drs. Syamsul Bahri, MM. Ak \& Rekan \\
3. & KAP Kanaka Puradiredja, Suhartono \\
4. & KAP Drs. Selamat Sinuraya \& Rekan (Pusat) \\
5. & KAP Andoko, S.E., M.Si., CPA \\
6. & KAP Fachrudin \& Mayhuddin \\
7. & KAP Hendrawinata Hanny Erwin \& Sumargo \\
\hline
\end{tabular}

Based on the results of the validity test, the questionnaire statement for the variable audit tenure, auditor experience, independency, task complexity, and audit judgment is said to be valid because the r-value of each statement is greater than the r-table value of 0.361 . As for the reliability test results, it is said that all are reliable because they have a Cronbach's Alpha value $>0.6$. Where the audit tenure variable has a Cronbach's Alpha value of 0.806 , auditor experience 0.808 , independency 0.873 , task complexity 0.625 , and audit judgment 0.832 .

Test the normality in statistical calculations used the one-sample Kolmogorov-Smirnov test shows that Asymp. Sig.(2-tailed) has a value of 0.958 , stating that the data is normally distributed because the value is greater than 0.05 .

By looking at the Tolerance and Variance Inflation Factor (VIF) values, shows that the tolerance values for each variable of audit tenure, auditor experience, independence, and task complexity are greater than 0.1 . Whereas for the VIF value of each variable is less than 10 , so it can be concluded that the variables do not occur with multicollinearity.

Heteroscedasticity testing in statistical calculations can use the Glejser test provided that the significance probability value is above 0.05 . Significance value for each variable are above the level of significance of confidence, it can be ascertained that this regression model does not have heteroscedasticity problems. For the results of multiple linear regression analysis, it can be seen in Table 2 . 
Table 2. Glejser Test

Coefficients $^{\mathrm{a}}$



a. Dependent Variable: ABCDEF

Testing the coefficient of determination $\left(\mathrm{R}^{2}\right)$ aims to determine how much the ability of the independent variable to explain the dependent variable (Table 3 ).

Table 3. Coefficient of Determination $\left(\mathrm{R}^{2}\right)$

Model Summary ${ }^{\mathrm{b}}$

\begin{tabular}{ccccc}
\hline Model & R & R Square & Adjusted R Square & Std. Error of the Estimate \\
\hline 1 & $.554^{\mathrm{a}}$ & .307 & .248 & 1.32429 \\
\hline
\end{tabular}

a. Predictors: (Constant), Task_Complexity, Independency, Auditor_Experience, Audit_Tenure

b. Dependent Variable: Audit_Judgement

It can be seen that the Adjusted R Square value obtained is 0.248 , which means that $24.8 \%$ of audit judgment variables can be explained by audit tenure, auditor experience, independence, and task complexity. Simultaneous hypothesis testing (Table 4) it can be seen that Fvalue $>$ Ftable $(5,211>2,569)$ which means that the audit tenure, auditor experience, independence, and task complexity variables simultaneously affect the audit judgment variable.

Tabel 4. F Test

ANOVA $^{\mathrm{a}}$

\begin{tabular}{llccccc}
\hline Model & & Sum of Square & $\mathrm{df}$ & Mean Square & F & Sig. \\
\hline 1 & Regression & 36.554 & 4 & 9.139 & 5.211 & $.001^{\mathrm{b}}$ \\
& Residual & 82.426 & 47 & 1.754 & & \\
& Total & 118.981 & 51 & & & \\
\hline
\end{tabular}

a. Dependent Variable: Audit Judgement

b. Predictors: (Constant), Task_Complexity, Independency, Auditor_Experience, Audit_Tenure

The results show that $t_{\text {value }}$ of audit tenure, auditor experience and independence is greater than $t_{\text {table, }}$ which is 2.012 , which means that these variables partially affect the audit judgment. However, in the task complexity variable, the $t_{\text {value }}$ is $\leq 2.012$ and $\geq-2.012$, which means that this variable does not partially affect the audit judgment.

\section{DISCUSSION}

First, audit tenure has a positive effect on audit jugdement. This condition supports that the longer an auditor cooperates with clients, the easier it is for auditors to design a more effective audit program and produce high quality audit judgments (Rustiarini and Sugiarti, 2011). The results of this study are in line with Sofiani and Tjondro (2014); Harahap \& Syalfia (2020) who state that an increased audit tenure will lead to an increase in audit judgment.

Second, auditor experience has a positive effect on audit judgment. The amount of experience an auditor has can make auditors learn from mistakes that have occurred in the past and will produce better decisions or judgments (Evi, et. al. 2014). This is in line with the research results of Sofiani and Tjondro (2014); Murthada (2018) which state that the more experienced an auditor is, the better his skills are in terms of completing work and the ability to provide the judgments taken. 
Third, independency has a positive effect on the audit jugement. An auditor who has a high level of independence is able to provide a more accurate judgment. This research is in line with Drupadi and Sudana (2015); Komalasari \& Hernawati (2015) who state that auditors with a good level of independence and skills will be able to provide better and more accurate opinions compared to auditors who only have one of these two factors.

Fourth, task complexity does not affect the audit jugement. Based on the results of the study, it shows that in a complex task situation, it does not affect the audit judgment taken by the auditors at public accounting firms in Medan City in determining their opinion or audit results. In other words, that the audit task faced by auditors tends to be less complex so that it does not have a significant effect on audit judgment. This shows that the auditors clearly know what tasks they will do, do not experience difficulties and can perform well the tasks they are responsible for (Fitriani and Daljono, 2012; Maghfirah \& Yahya, 2018).

This research is in line with Fitriani and Daljono (2012) as well Maghfirah and Yahya (2018) who state that task complexity does not have a significant effect on audit judgment.

\section{CONCLUSION}

Audit tenure has a positive and significant effect on audit judgment. The longer an auditor cooperates with the client, the easier it is for the auditor to design a more effective audit program, so that it will produce a high quality audit judgment. Auditor experience has a positive and significant effect on audit judgment. The more experience the auditor has, the better and more correct decisions will be. Independency has a positive and significant effect on audit judgment. Auditors who have a good level of independence and skills will be able to provide better and more accurate opinions. Task complexity has no effect on the audit judgment. Audit tenure, auditor experience, independency, and task complexity simultaneously have an effect on audit judgment at the public accounting firm in Medan City.

\section{REFERENCES}

Adnyani, D., Latrini, M. Y. and Widhiyani, N. L. S. 2020. The Influence of Time Budget Pressure, Audit Complexity and Audit Fee on Audit Quality (Case Study at Public Accounting Firms in Bali Province). Timor Leste Journal of Business and Management, 2(1), pp. 27-32.

Asmara, R. Y. and Situanti, R. 2018. The effect of audit tenure and firm size on financial reporting delays. European Research Studies Journal, 21(3), pp. 414-422.

Bessie, D. M. 2010. Pengaruh Pengalaman Auditor Eksternal dan Audit Tenure terhadap Kualitas Audit. (Online): https://elib.unikom.ac.id/files/disk1/643/jbptunikompp-gdl-dianmulyas-32123-9-unikom_d-l.pdf

Drupadi, M.J. and Sudana, I.P., 2015. Pengaruh Keahlian Auditor, Tekanan Ketaatan dan Independensi Pada Audit Judgment. E-Jurnal Akuntansi, 12(3), pp.623-655.

Eny, N. and Mappanyukki, R. 2020. Moderating Role of Audit Fees on the Effect of Task Complexity and Independence towards Audit Judgment. Journal of Economics, Business, \& Accountancy Ventura, 23(2), pp. 194-204.

Evi, A. K, Edy, S. and Nyoman, D. A. S. 2014. Pengaruh Pengalaman Auditor, Tekanaan Ketaatan dan Kompleksitas Tugas terhadap Audit Judgment(Studi Empiris Pada BPKP Perwakilan Provinsi Bali). Jurnal Bisnis Manajemen dan Ekonomi, 2(1).

Fitriani, S. and Daljono. 2012. Pengaruh Tekanan Ketaatan, Kompleksitas Tugas, Pengetahuan dan Persepsi Etis Terhadap Audit Judgement. Diponegoro Journal Of Accounting, 1(1), pp. 1-12.

Harahap, R. U. and Syalfia, D. I. 2020. Pengaruh Audit Tenure dan Due Professional Care terhadap Audit Judgment pada Kantor Akuntan Publik di Medan. Literasi Literasi, 2(1), pp. 13-26.

Hasan, M. A. and Andreas, A. 2019. A Study of Audit Judgment in The Audit Process: Effects of Obedience Pressures, Task Complexity, and Audit Expertise-The Case of Public Accounting Firms in SumatraIndonesia. International Journal of Scientific and Technology Research, 8(7), pp. 32-37.

Komalasari, R. and Hernawati, E. 2015. Pengaruh Independensi, Kompleksitas Tugas, Dan Gender Terhadap Audit Judgment. Neo-bis, 9(2), pp. 66-86.

Maghfirah, I. and Yahya, M. R. 2018. Pengaruh Kompleksitas Tugas, Self-Efficacy, dan Pengalaman Audit Terhadap Audit Judgement (Studi Pada Auditor Bpk Ri Perwakilan Provinsi Aceh). Jurnal Ilmiah Mahasiswa Ekonomi Akuntansi (JIMEKA), 3(2), pp. 276-288.

Murtadha, I. A. 2018. Pengaruh Gender, Anggaran Waktu Dan Pengalaman Auditor Terhadap Audit Judgement (Studi Empiris Pada Kantor Akuntan Publik (KAP) dan Badan Pemeriksa Keuangan (BPK) di Sumatra Barat). E-Jurnal Ekonomi dan Bisnis, (1), pp. 1-19. 
Noor, I. N., Pujianthi, E. and Hamun, M. 2019. Effect of Audit Expertise, Compliance Pressure, Task Complexity, and Experience on Audit Judgement. Mega Aktiva : Jurnal Ekonomi dan Manajemen Mega Aktiva : Jurnal Ekonomi dan Manajemen, 8(2), pp. 100-112.

Pinto, M., Rosidi, R. and Baridwan, Z. 2020. Effect of Competence, Independence, Time Pressure and Professionalism on Audit Quality (Inspeção Geral Do Estado in Timor Leste). International Journal of Multicultural and Multireligious Understanding, 7(8), p. 658.

Praditaningrum, A. S. C. 2012. Analisis Faktor-Faktor yang Berpengaruh terhadap Audit Judgment (Studi Pada BPK RI Perwakilan Provinsi Jawa Tengah). Skripsi, Program Sarjana Fakultas Ekonomi dan Bisnis Universitas Diponegoro, Semarang.

Priyoga, I. and Ayem, S. 2019. Pengaruh Tekanan Ketaatan, Gender, Kompleksitas Tugas, Independensi, Dan Pengalaman Auditor Terhadap Audit Judgment. Kajian Bisnis STIE Widya Wiwaha, 27(1), pp. 63-74.

Putra, A. M. T. 2016. Pengaruh Gender, Kompleksitas Tugas, Pengalaman Auditor, Dan Kompetensi Profesional Terhadap Audit Judgement (Studi Empiris pada Auditor Kantor Akuntan Publik di Wilayah DKI Jakarta dan Tangerang Periode 2016). Jurnal Akuntansi dan Keuangan FE Universitas Budi Luhur, 5(2), pp. 80-100.

Putri, T. M. 2014. Pengaruh Auditor Tenure, Ukuran Kantor Akuntan Publik, dan Ukuran Perusahaan Klien terhadap Kualitas Audit (Studi Empiris pada Perusahaan Manufaktur yang Terdaftar di BEI pada Tahun 2010-2012). Diponegoro Journal of Accounting, 3(2), pp. 1130-1140.

Rozalina, N. and Rachmat, D. 2020. The Effect Of Compliance Pressure, Auditor's Experience, and Task Complexity Towards Audit Judgement ( case study at the Public Accountant Office of East Jakarta ). (Online): http://repository.stei.ac.id/2862/2/11150000214_Artikel\%20Inggris_\%202020.pdf

Rustiarini, N. W. and Sugiarti, N. W. M. 2011. Pengaruh Karakteristik Auditor, Opini Audit, Audit Tenure, Pergantian Auditor pada Audit Delay. Jurnal JINAH: Jurnal Ilmiah Akuntansi dan Humanika, Vol.2 No. 2, pp. 657-675.

Saputra, J. and Muhammad, Z. 2019. The Effect of Audit Knowledge, Audit Document Complexity and Auditor Experience Towards Audit Judgement of Internal Auditor in West Aceh Inspectorate Office, Indonesia. Universiti Malaysia Terengganu Journal of Undergraduated Research, Vol.1 No.2, pp. 111117.

Sari, D. and Ruhiyat, E. 2017. Pengaruh Locus of Control, Tekanan Ketaatan Dan Kompleksitas Tugas Terhadap Audit Judgment. Jurnal ASET (Akuntansi Riset), 9(2), p. 23.

Sari, S. P., Diyanti, A. A. and Wijayanti, R. 2019. The Effect of Audit Tenure, Audit Rotation, Audit Fee, Accounting Firm Size, and Auditor Specialization to Audit Quality. Riset Akuntansi dan Keuangan Indonesia, 4(3), pp. 186-196.

Sila, M. et al. 2015. The Effect of Knowledge and Experience on Professional Auditor's Judgment: Study on State Auditor in Indonesia. International Journal of Management and Administrative Sciences (IJMAS), 3(10), pp. 98-106.

Sitohang, M. 2016. The Effect of Task Complexity, Independency, and Experience on Audit Judgment(Empirical Study on Public Accounting Firm in Dki Jakarta. (Online): http://repository.president.ac.id/xmlui/ handle/123456789/1757.

Sofiani, M.M.O.L., and Tjondro, E. 2014. Pengaruh Tekanan Ketaatan, Pengalaman Audit, dan Audit Tenure Terhadap Audit Judgment. Tax \& Accounting Review, Vol.4(No.1), pp. 2-10.

Susanto. 2020. The Effect of Task Complexity, Independence and Competence on The Quality of Audit Results with Auditor Integrity as a Moderating Variable. International Journal of Innovation, Creativity and Change, 12(12), pp. 742-755.

Upawita, K. and Pertiwi, C. 2017. Pengaruh Tekanan Ketaatan, Independensi, Pengalaman Kerja, Locus of Control Terhadap Audit Judgment Di Kap Bali. E-Jurnal Akuntansi, 19(1), pp. 712-740.

Widyakusuma, A., Sudarma, M. and Roekhudin, R. 2019. The Effect of Professionalism and Experience on Audit Judgment with Task Complexity as a Moderating Variable. International Journal of Multicultural and Multireligious Understanding, 6(2), p. 97.

Williams, L. T. 2016. The Impact of Disclosing Auditor Independence and Tenure on Non- Professional Investor Judgment and Decision-Making. Electronic Theses and Dissertations, pp. 1-115.https://egrove. olemiss.edu/etd $/ 352$

https://iapi.or.id/Iapi/detail/924 